\title{
Progressive Endoplasmic Reticulum Stress Contributes to Hepatocarcinogenesis in Fatty Acyl-CoA Oxidase 1-Deficient Mice
}

\author{
Jiansheng Huang, ${ }^{*}$ Navin Viswakarma, ${ }^{*}$ \\ Songtao Yu, ${ }^{*}$ Yuzhi Jia, ${ }^{*}$ Liang Bai, ${ }^{\star \dagger}$ \\ Aurore Vluggens, ${ }^{*}$ Mustapha Cherkaoui-Malki, ${ }^{\ddagger}$ \\ Mushfiquddin Khan, ${ }^{\S}$ Inderjit Singh, ${ }^{\S}$ \\ Gongshe Yang, ${ }^{\dagger}$ M. Sambasiva Rao, ${ }^{*}$ \\ Jayme Borensztajn, ${ }^{*}$ and Janardan K. Reddy* \\ From the Department of Pathology, Feinberg School of Medicine, \\ Northwestern University, Chicago, Illinois; the Laboratory of Animal Fat \\ Deposition and Muscle Development, ${ }^{\dagger}$ College of Animal Science and \\ Technology, Northwest A \& F University, Shaanxi, China; the Centre de \\ Recherche INSERM U866-Biochimie Métabolique et Nutritionnelle, ${ }^{\ddagger}$ \\ Université de Bourgogne, Dijon, France; and the Department of \\ Pediatrics, ${ }^{\circledR}$ Charles Darby Children's Research Institute, Medical \\ University of South Carolina, Charleston, South Carolina
}

Fatty acyl-coenzyme A oxidase 1 (ACOX1) knockout $\left(\mathrm{ACOX}^{-/-}\right)$mice manifest hepatic metabolic derangements that lead to the development of steatohepatitis, hepatocellular regeneration, spontaneous peroxisome proliferation, and hepatocellular carcinomas. Deficiency of ACOX1 results in unmetabolized substrates of this enzyme that function as biological ligands for peroxisome proliferator-activated receptor- $\alpha(\operatorname{PPAR} \alpha)$ in liver. Here we demonstrate that sustained activation of PPAR $\alpha$ in ACOX1 $^{-/-}$mouse liver by these ACOX1 substrates results in endoplasmic reticulum (ER) stress. Overexpression of transcriptional regulator $\mathrm{p} 8$ and its ER stress-related effectors such as the pseudokinase tribbles homolog 3 , activating transcription factor 4, and transcription factor CCAAT/-enhancerbinding protein homologous protein as well as phosphorylation of eukaryotic translation initiation factor $2 \alpha$, indicate the induction of unfolded protein response signaling in the $\mathrm{ACOX}^{-/-}$mouse liver. We also show here that, in the liver, $\mathrm{p} 8$ is a target for all three PPAR isoforms $(-\alpha,-\beta$, and $-\gamma)$, which interact with peroxisome proliferator response elements in $p 8$ promoter. Sustained activation of $p 8$ and unfolded protein response-associated ER stress in $\mathrm{ACOX1}^{-/-}$mouse liver contributes to hepatocyte apoptosis and liver cell proliferation culminating in the development of hepatocarcinogenesis. We also demonstrate that human ACOX1 transgene is functional in $\mathrm{ACOX} 1^{-/-}$mice and effectively prevents metabolic dysfunctions that lead to ER stress and carcinogenic effects. Taken together, our data indicate that progressive PPAR $\alpha$ and p8-mediated ER stress contribute to the hepatocarcinogenesis in ACOX1 ${ }^{-/-}$mice. (Am J Pathol 2011, 179:703-713; DOI: 10.1016/j.ajpath.2011.04.030)

Fatty liver disease is a burgeoning chronic liver disorder, commencing with hepatic steatosis and steatohepatitis, that has a propensity to progress toward cirrhosis and liver cancer. ${ }^{1-3}$ The pathological spectrum of fatty liver disease, caused by either alcoholic or nonalcoholic conditions, suggests a possible convergence, at some critical juncture, of pathogenetic mechanisms that enable the progression of steatosis toward steatohepatitis. ${ }^{3-5}$ This transition could contribute to events responsible for liver cell death, hepatocellular proliferation, and stellate cell activation, all of which are critical in the progression to cirrhosis and liver cancer. ${ }^{3,6}$ Increasingly, mice with genetic ablations of selected pathways in hepatic lipid metabolism and of other signal transduction networks are serving as important models to investigate the pathogenetic mechanism of fatty liver disease..$^{7-13}$ For example, disruption of peroxisomal fatty acyl-CoA oxidase 1 (ACOX1) gene in the mouse has been shown to result in the development of steatohepatitis and increased expression of genes regulated by peroxisome proliferatoractivated receptor $\alpha$ (PPAR $\alpha){ }^{8,10}$ ACOX 1 is the first and a rate-limiting enzyme of the PPAR $\alpha$-regulated and per-

Supported in part by National Institutes of Health grants GM23750 and DK083163 (J.K.R) and by the China Scholarship Council (L.B.).

Accepted for publication April 25, 2011.

Supplemental material for this article can be found at http://ajp. amjapthol.org or at doi: 10.1016/j.ajpath.2011.04.030.

Address reprint requests to Janardan Reddy, M.D., Department of Pathology, Feinberg School of Medicine, Northwestern University, 303 East Chicago Avenue, Chicago, IL 60611. E-mail: jkreddy@northwestern.edu. 
oxisome proliferator-inducible fatty acid $\beta$-oxidation system. ${ }^{11-14}$ Mice deficient in ACOX1 exhibit growth retardation, high levels of very long chain fatty acids, microvesicular steatohepatitis, apoptosis, liver regeneration, and oxidative stress, and these mice eventually develop hepatocellular carcinomas. ${ }^{8,10,15,16}$

We hypothesized that the unmetabolized substrates of ACOX 1 , mainly fatty acids and their derivatives, function as endogenous ligands for PPAR $\alpha$ to induce sustained peroxisome proliferation and elevation of PPAR $\alpha$ target gene expression, contributing to the development of liver cancer. ${ }^{8,10,14-17}$ Steatohepatitis, increased levels of hepatic hydrogen peroxide content, and increased hepatocellular apoptosis and proliferation resulting from disturbances in fatty acid oxidation in the ACOX $1^{-1-}$ mouse, ${ }^{10}$ suggested a potential role for endoplasmic reticulum (ER) stress in this model, as excess lipid accumulation in tissues is linked to the development of ER stress. ${ }^{9,18-22}$ In this study, we first demonstrate that ACOX1-deficient livers exhibit progressive ER stress with activation of unfolded protein response signaling, with increases in the levels of ER stress response markers such as phosphorylated eukaryotic translation initiation factor $2 \alpha$ (p-elF2 $\alpha$ ), activating transcription factor (ATF) 4 , glucose regulated protein 78 (GRP78), C/EBP homologous protein (CHOP/ CHOP10), GADD45 $\alpha$, pseudokinase tribbles homolog 3 (TRB3), Bax, Bclll, and Nrf2. ${ }^{18-29}$ Furthermore, we provide evidence to suggest that ER stress is induced by hyperactivation of PPAR $\alpha$, which in turn upregulates the expression of stress-modulated transcription factor p8 [also known as nuclear protein 1 (NUPR1)] ${ }^{26-29}$ and its ER stress-related downstream targets ATF4, CHOP, and TRB3. Thus, sustained PPAR $\alpha$ activation and its induction of $p 8$ expression in the liver by the unmetabolized substrates of ACOX1 in mice nullizygous for ACOX1, contributes to ER stress and may contribute to the development of hepatocellular carcinoma. The data presented here also indicate that transgenic expression of human ACOX 1 in $\mathrm{ACOX}^{-1-}$ mice prevents the development of metabolic dysfunctions including steatohepatitis spontaneous activation of PPAR $\alpha$, steatohepatitis, liver cancer, and unfolded protein response signaling. These observations indicate that human ACOX1 gene functionally replaces mouse ACOX1 gene and that this enzyme keeps the PPAR $\alpha$ endogenous ligands in check and prevents sustained activation of this transcription factor.

\section{Materials and Methods}

\section{ACOX $1^{-1-}$ Mice and Generation of $A C O X 1^{-1-}$ with Human ACOX1 Transgene (ACOX1-1-h+ Humanized Mice)}

The human bacterial artificial chromosome (BAC) clone CTD2336I6, containing the human ACOX1 genomic DNA and its promoter, was purchased from Invitrogen Corporation (Carlsbad, CA). This BAC DNA was trimmed to $\sim 90 \mathrm{~kb}$ using homologous recombination in bacteria to excise flanking genes and then replaced with an ampicilin resistance gene using primers shown in Table 1. BAC transgenic
Table 1. Oligonucleotide Sequences of Trimming BAC Clone, Genotyping, Real-Time PCR Primers, and Northern Probes

\begin{tabular}{|c|c|}
\hline $\begin{array}{l}\text { Trimming BAC } \\
\text { clone }\end{array}$ & $\begin{array}{l}\text { 5' - GGGTGCAAATTGCCCGGTGCCTTCTG } \\
\text { TTTCCCAGGCAGCTCTGTG-3' } \\
\text { 5' - CAGCTTACCTCTCAGGAATGCTACGT } \\
\text { TTTGAACATCAAGAATGGAAA-3' }\end{array}$ \\
\hline \multicolumn{2}{|r|}{ 1 1 tom } \\
\hline Sense & $\begin{array}{c}5^{\prime} \text { - GCCATGGATATGTTCCAGAAGGTAGC } \\
\text { TTGGTCTGACAGTTACCAATGC-3' }\end{array}$ \\
\hline Antisense & $\begin{array}{l}\text { 5'-GCTGCCATTGAGGCTTTTAACAAAG } \\
\text { GTGGCACTTTTC-3' }\end{array}$ \\
\hline \multicolumn{2}{|l|}{$\begin{array}{l}\text { Genotyping } \\
\text { Neo }\end{array}$} \\
\hline Sense & 5'-TATTCGGCTATGACTGGGCACA-3' \\
\hline $\begin{array}{l}\text { Antisense } \\
\text { mACOX1 exon }\end{array}$ & 5'-GATGGATACTTTCTCGGCAGGA-3' \\
\hline Sense & $5^{\prime}-\mathrm{CCGCAAGCCATCCGACATTC-3^{ \prime }}$ \\
\hline $\begin{array}{c}\text { Antisense } \\
\text { hACOX1BAC }\end{array}$ & 5'-ATTCAGTGGGTCAGGCGACTGC-3' \\
\hline Sense & 5'-ATTGCCCGGTGCCTTCTGTTTC-3' \\
\hline Antisense & 5'-AGCCGGTGAGCGTGGGTCTC-3' \\
\hline \multicolumn{2}{|l|}{ qPCR/Probe } \\
\hline Forward & $5^{\prime}-\mathrm{TCTGTCTGGGCCGCTGTCACTC-3^{ \prime }}$ \\
\hline \multicolumn{2}{|r|}{ - } \\
\hline Forward & $5^{\prime}-$ GCCAAGGCGACCTGAGTGAGC-3' \\
\hline Reverse & $5^{\prime}-$ ACCGCAAGCCATCCGACATTC-3' \\
\hline \multicolumn{2}{|r|}{ 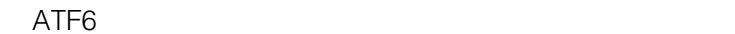 } \\
\hline Forward & $5^{\prime}$-CAGTTGCTCCATCTCCTCTCC-3' \\
\hline Reverse & 5'-TGGGACACTGGCATTGGTTTG-3' \\
\hline \multicolumn{2}{|r|}{ S -IGGGACALIGGLAIIGSIIIG-S } \\
\hline Forward & $5^{\prime}$-CCTGAGCCCGGAGGAGAA-3' \\
\hline Reverse & $5^{\prime}-$ CTCGAGCAGTCTGCGCTG- $3^{\prime}$ \\
\hline \multicolumn{2}{|r|}{ 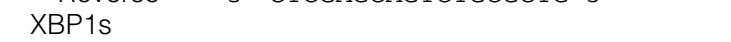 } \\
\hline Forward & $5^{\prime}-$ ACACGCTTGGGAATGGACAC-3' \\
\hline \multirow{2}{*}{\multicolumn{2}{|c|}{ ว -CLATGGGAAGATGITLIGGG-3 }} \\
\hline & \\
\hline Forward & $5^{\prime}$-ACTATCTGGAGGTGGCCAAG-3' \\
\hline Reverse & $5^{\prime}$-CATCCAACGTGGTCAAGAGC- $3^{\prime}$ \\
\hline \multicolumn{2}{|r|}{ J -CAILCAALGIGGICAAGAGL-J } \\
\hline Forward & $5^{\prime}-$ CGTGGAGATCATAGCCAACG-3' \\
\hline Reverse & $5^{\prime}$-ATACGCCTCAGCAGTCTCCT-3' \\
\hline \multicolumn{2}{|r|}{ 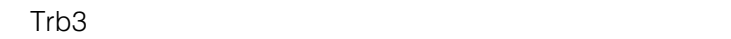 } \\
\hline Forward & 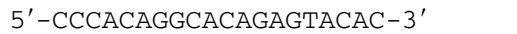 \\
\hline Reverse & 5'-CGTCCTCTCACAGTTGCTGA-3' \\
\hline \multicolumn{2}{|r|}{ 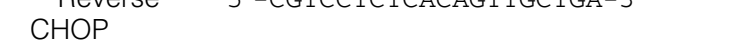 } \\
\hline Forward & $5^{\prime}$-AGCCTGGTATGAGGATCTGC-3' \\
\hline Reverse & 5'-СТССТGCTCСТTCTCСТTCA-3' \\
\hline \multicolumn{2}{|r|}{ 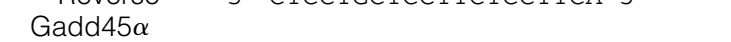 } \\
\hline Forward & $5^{\prime}$-CCAAGCTGCTCAACGTAGA-3' \\
\hline Reverse & 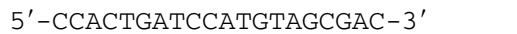 \\
\hline \multicolumn{2}{|l|}{ P8 } \\
\hline Forward & $5^{\prime}-$ ACCAAGAGAGAAGCTGCTGC-3' \\
\hline \multirow{2}{*}{\multicolumn{2}{|c|}{5 -CICLCILCCAGAACLICACI-3 }} \\
\hline & \\
\hline Forward & 5'-CCACAGTTGATTTCTCCAGCATTTC-3' \\
\hline Reverse & $5^{\prime}$-CAGGTTCTACTTTGATCGCACTTTG- $3^{\prime}$ \\
\hline \multicolumn{2}{|r|}{ 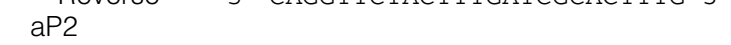 } \\
\hline Forward & 5'-GAAGTGGGAGTGGGCTTTGC-3' \\
\hline Reverse & 5'-TGTGGTCGACTTTCCATCCC-3' \\
\hline \multicolumn{2}{|r|}{ - } \\
\hline Forward & $5^{\prime}$-ACCAAGAAGCTGAGCGAGTG-3' \\
\hline Reverse & $5^{\prime}-$ CTCACGGAGGAAGTCCAGTG- $3^{\prime}$ \\
\hline \multicolumn{2}{|r|}{ S -CICALGGAGGAAGILCAGIG-S } \\
\hline Forward & 5'-ТСTTCTCСТTCCAGCCTGAG-3' \\
\hline Reverse & $5^{\prime}-$ CCCACCGAACTCAAAGAAGG- $3^{\prime}$ \\
\hline \multicolumn{2}{|r|}{ 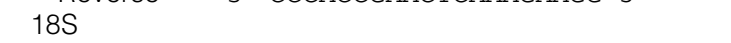 } \\
\hline Forward & $5^{\prime}-$ AAACGGCTACCACATCCAAG-3' \\
\hline Reverse & $5^{\prime}$-CCTCCAATGGATCCTCGTTA-3' \\
\hline
\end{tabular}

$\mathrm{BAC}=$ bacterial artificial chromosome. 
mice were generated by zygotic pronuclear microinjection in the Transgenic and Targeted Mutagenesis Laboratory, Northwestern University (Chicago, IL). Human BAC transgenic founders were then backcrossed with $\mathrm{ACOX} 1^{+/-}$ mice ${ }^{8,10}$ to generate $\mathrm{ACOX} 1^{+/-}$mice containing human ACOX1 transgene $\left(\mathrm{ACOX} 1^{+/-\mathrm{h}+}\right)$. The $\mathrm{ACOX} 1^{+/-\mathrm{h}+}$ mice were then mated with $\mathrm{ACOX} 1^{+/-}$mice to generate $\mathrm{ACOX} 1^{-1-}$ humanized mice $\left(\mathrm{ACOX} 1^{-1-\mathrm{h}+}\right)$, and ACOX $1^{-1-}$ and wild-type littermates. Mice used in this study were housed using 12-hour light, 12-hour dark cycle, in a pathogen-free animal facility and maintained on standard rodent chow (Harlan-Teklad, Indianapolis, IN) and water ad libitum. The PPAR $\alpha$ synthetic ligand Wy-14,643 [4chloro-6-(2,3-xylidino)-2-pyrimidinylthio]acetic acid] $(0.125 \% \mathrm{w} / \mathrm{w})$ was administered in chow. ${ }^{10,30,31}$ For cell proliferation analysis, mice were administered bromodeoxyuridine (BrdUrd) in drinking water $(0.5 \mathrm{mg} / \mathrm{mL})$ for 4 days and their livers processed for immunohistochemical localization of BrdUrd. ${ }^{32,33}$ All animal procedures used in this study were reviewed and preapproved by the Northwestern University Institutional Animal Care and Use Committee.

\section{Morphology}

Livers were fixed in $4 \%$ paraformaldehyde and embedded in paraffin. Sections $5 \mu \mathrm{m}$ in thickness were stained with hematoxylin and eosin (H\&E) or Sirius Red, or processed for immunohistochemical localization of BrdUrd. ${ }^{31,32}$ Terminal deoxynucleotidyl transferase-mediated dUTP nick-end labeling (TUNEL) assay (Roche Molecular Biochemicals, Mannheim, Germany) was performed with fluoresceindUTP following the manufacturer's instructions. Electron microscopy and histochemical localization of peroxisomal catalase were performed as described elsewhere. ${ }^{10,31}$

\section{Serum and Hepatic Lipid}

Sera were analyzed for very long chain fatty acids C26: 0/C22:0 and C24:0/C22:0 as described previously. ${ }^{8}$ For hepatic triglyceride and cholesterol levels, $100 \mathrm{mg}$ of liver was homogenized for extraction of lipid by chloroform/ methanol extraction assay. Total lipid was resuspended in 5\% Triton $X-100$ in phosphate-buffered saline, and levels of triglyceride and total cholesterol were then quantified according to the manufacturer's procedures. ${ }^{34}$

\section{Cell Culture}

Mouse primary hepatocytes from 1-month-old C57BL6/J mice were isolated by collagenase II perfusion and cultured as reported. ${ }^{33} \mathrm{Wy}-14,643$ (25 $\mu \mathrm{mol} / \mathrm{L}$ or $\left.50 \mu \mathrm{mol} / \mathrm{L}\right)$ was added to the culture medium, and cells were harvested 48 hours later. Mouse embryonic fibroblasts were prepared from $\mathrm{ACON}^{-1-}$ fetuses that were harvested at day 13.5 of gestation. ${ }^{35}$ Fetuses were dissected and incubated with $20 \mathrm{~mL}$ of $0.05 \%$ trypsin (Gibco, Carlsbad, CA) at $37^{\circ} \mathrm{C}$ for 25 minutes. Cells were cultured in Dulbecco's modified Eagle's medium with 10\% fetal bovine serum and $1 \%$ L-glutamine. For siRNA transfection, mouse p8 siRNA oligos (catalog no. sc-40793) and its negative control (catalog no. sc-37007) were purchased from Santa Cruz Biotechnology (Santa Cruz, CA). The ACOX $1^{-1-}$ mouse embryonic fibroblasts were cultured in $60-\mathrm{mm}$ plates overnight. Cells were transfected with $1 \mu \mathrm{g}$ or $3 \mu \mathrm{g}$ of $\mathrm{p} 8$ siRNA or with $3 \mu \mathrm{g}$ negative control siRNA using Lipofectamine 2000 (Invitrogen). RNA was extracted from the cells 2 days after transfection and used for quantitative PCR (qPCR) analysis.

\section{Gene Expression Analysis}

For qPCR, total RNA was isolated with TRIzol reagent (Invitrogen) and reverse transcribed using $2 \mu \mathrm{g}$ of total RNA. The primer sequences used are listed in Table 1. Northern and Western blotting procedures used were as described elsewhere. ${ }^{31,32}$

\section{Chromatin Immunoprecipitation and Electrophoretic Mobility Shift Assay}

Chromatin was prepared from liver nuclei and used for chromatin immunoprecipitation (ChIP) assays as described elsewhere. ${ }^{34}$ For the gel shift assay, the in vitro translated $\operatorname{PPAR} \alpha, \operatorname{PPAR} \gamma$, and $\operatorname{PPAR} \beta / \delta$ protein was incubated with $\gamma^{32}$ P-labeled wild-type P1, P2, or P3 duplex oligonucleotides, and DNA-protein complexes were resolved using $4 \%$ acrylamide nondenatured gels. ${ }^{36}$ Primers and oligonucleotides used for these assays are listed in Table 2.

Table 2. Oligonucleotide Sequences of ChIP Assay and EMSA Primers

\begin{tabular}{|c|c|}
\hline \multicolumn{2}{|l|}{ ChIP assay } \\
\hline \multicolumn{2}{|l|}{$\mathrm{P} 1$} \\
\hline Forward & $5^{\prime}$-CTGACGGAAGGAAGGTTGTT-3' \\
\hline Reverse & $5^{\prime}-$ TGGCTCATTTAGAGACACGC-3' \\
\hline \multicolumn{2}{|l|}{ P2 } \\
\hline Forward & $5^{\prime}-$ CAGCCAGACCAGAAATTGTC-3' \\
\hline Reverse & $5^{\prime}$-GAGCCCATTGCACTTAGATG-3' \\
\hline \multicolumn{2}{|r|}{ 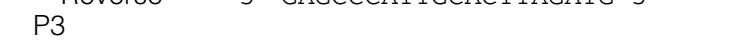 } \\
\hline Forward & $5^{\prime}-$ СTCAGACCTCAGGCCACTCT-3' \\
\hline Reverse & $5^{\prime}$-CTTGGTGAGCTGGTGAGAAA-3' \\
\hline \multirow{2}{*}{\multicolumn{2}{|c|}{$\begin{array}{l}\text { EMSA } \\
\text { P1 }\end{array}$}} \\
\hline & \\
\hline Sense & $\begin{array}{c}5^{\prime} \text {-GGCACACCATCAAAGGGGAAAAGGTCA } \\
\text { GAGGTTGGAAAACCTGAGCTCA-3' }\end{array}$ \\
\hline Antisense & $\begin{array}{l}5^{\prime} \text { - GAGACTCTGAGCTCAGGTTTTCCAACC } \\
\text { TCTGACCTTTTCCCCTTGAT-3' }\end{array}$ \\
\hline \multicolumn{2}{|r|}{ - - } \\
\hline Sense & $\begin{array}{l}5^{\prime} \text { - GGATATGTCCCTGAGAGTTGCAGCTGA } \\
\text { CCCACAGCCTGCTGTGAGGCCACT- } 3^{\prime}\end{array}$ \\
\hline Antisense & $\begin{array}{c}5^{\prime} \text {-GGAATCAGTGGCCTCACAGCAGGCTGT } \\
\text { GGGTCAGCTGCAACTCTCAGGGA-3' }\end{array}$ \\
\hline \multicolumn{2}{|r|}{ 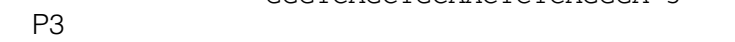 } \\
\hline Sense & $\begin{array}{l}5^{\prime} \text {-GAGTAAAATTGCAACATTCCAAACTCA } \\
\text { GACCTCAGGCCACTCTACACTTGGT- }{ }^{\prime}\end{array}$ \\
\hline Antisense & $\begin{array}{l}5^{\prime} \text { - GGTTGAACCAAGTGTAGAGTGGCCTGA } \\
\text { GGTCTGAGTTTGGAATGTTGCAATT-3' }\end{array}$ \\
\hline
\end{tabular}

ChIP = chromatin immunoprecipitation; EMSA = electrophoretic mobility shift assay. 

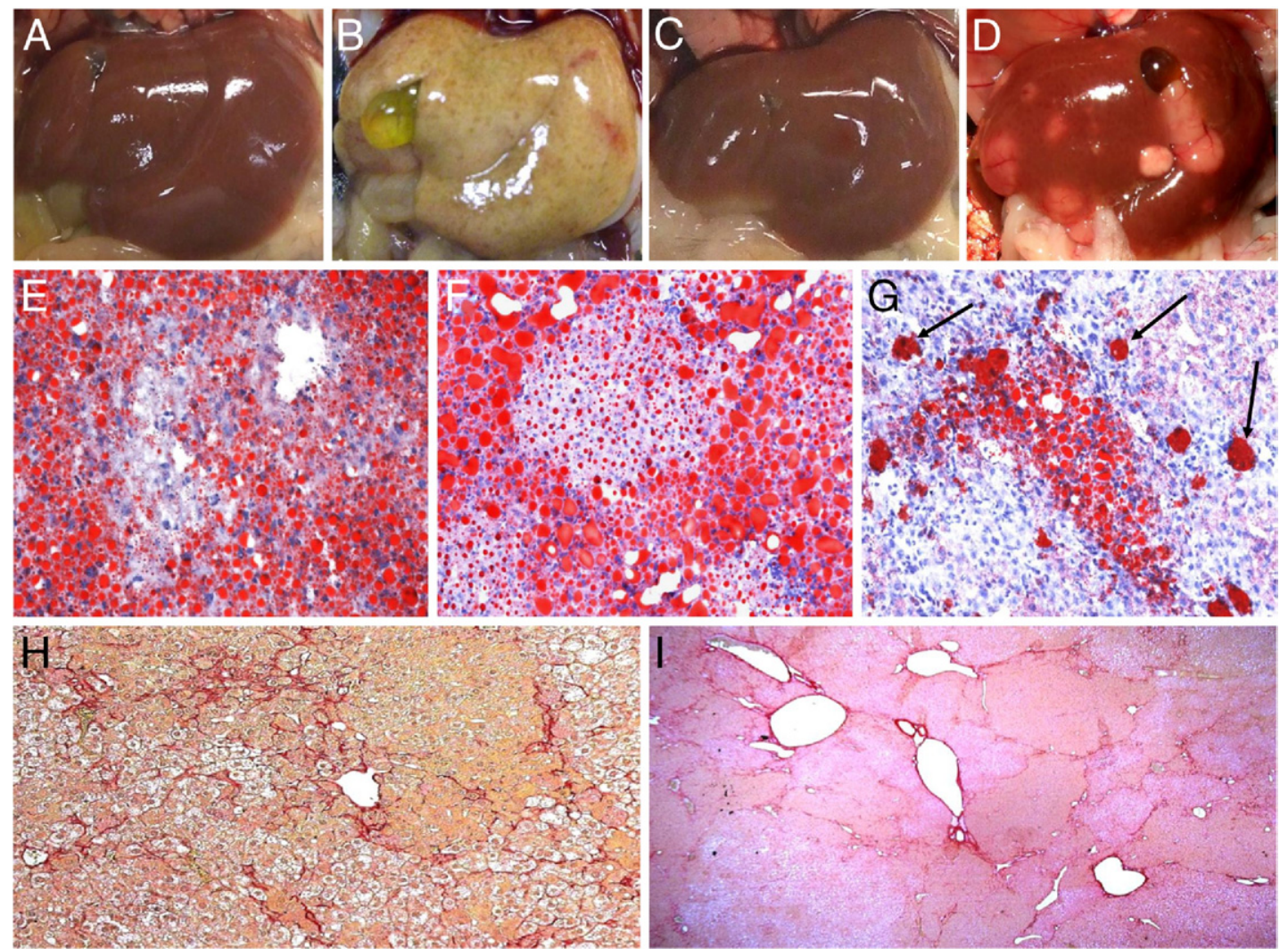

Figure 1. Progression from steatohepatitis to hepatocellular carcinoma in ACOX1 ${ }^{-/-}$mice. Liver of 2 -month-old wild-type (A) and ACOX1 ${ }^{-/-}$mouse (B); 1-year-old wild-type $(\mathbf{C})$ and ACOX1 ${ }^{-1-}$ mouse liver with liver tumors (D). Oil Red O staining of liver from 2-month-old (E), 5-month-old (F), and 8-month-old (G) $\mathrm{ACOX}^{-1-}$ mice. Proliferating hepatocytes reveal lessening of steatosis. By 8 months of age, only a few clusters of hepatocytes and a few macrophages (arrows) remain steatotic $(\mathbf{G})$. Sirius red staining of liver from an 8-month-old $(\mathbf{H})$ and a 1-year-old $(\mathbf{I})$ ACOX1 ${ }^{-/-}$mouse.

\section{Statistical Analysis}

Data were analyzed using one-way analysis of variance, with values of $P<0.05$ considered to be significant.

\section{Results}

\section{Steatohepatitis, Lipoapoptosis, Hepatocellular Regeneration, and Hepatocarcinogenesis in ACOX $1^{-1-}$ Mice}

Young $\mathrm{ACOX}^{-1-}$ mice exhibit severe hepatic steatosis and evidence of hepatocellular regeneration (Figure 1, $\mathrm{A}-\mathrm{I}$, and Figure 2, $\mathrm{A}-\mathrm{I}$ ). The hepatic triglyceride, but not total cholesterol, was increased in ACOX $1^{-/-}$mice at the age of 5 months (see Supplemental Figure $\mathrm{S} 1$ at $h$ ttp:// ajp.amjpathol.org). A reduction in the extent of hepatic fatty change occurs in older ACOX $1^{-1-}$ mice, which by then develop grossly visible liver tumors (Figure 1D). Clusters of foamy macrophages loaded with Oil Red O-positive material are seen scattered in the liver parenchyma in ACOX $1^{-1-}$ mice 8 months or older (Figure 1G). These livers also displayed increased amounts of fibrosis as evidenced by portal-to-portal and portal-to-central vein bridging strands of Sirius red-positive collagen (Figure $1, \mathrm{H}$ and I). Regenerated hepatocytes are resistant to fatty change (Figure 2, B and C) and display abundant granular cytoplasm indicative of peroxisome proliferation (Figure 2B). These cells repopulate liver and gradually replace steatotic hepatocytes. BrdUrd immunohistochemical staining confirmed increase in liver cell proliferation in ACOX $1^{-1-}$ mice (Figure 2, D-F). Terminal deoxynucleotidyl transferase-mediated dUTP nick-end labeling staining of liver sections revealed age-related increased level of hepatocyte apoptotic activity in $\mathrm{ACOX}^{-1-}$ mice, reflecting death of some steatotic liver cells (Figure 2, G-I).

\section{Aggravated ER Stress in $\mathrm{ACOX}^{-1-}$ Mouse Liver}

ACOX $1^{-1-}$ mice exhibit steatohepatitis, increased hepatic levels of $\mathrm{H}_{2} \mathrm{O}_{2}$, and hepatocellular regeneration. ${ }^{8,10}$ Progression of hepatic manifestations in ACOX $1^{-1-}$ mice prompted us to examine whether these mice would manifest ER stress in view of the sustained activation of PPAR $\alpha$ by ACOX 1 substrates that remain unmetabolized in the absence of ACOX1 and function as endogenous activators of this nuclear receptor. ${ }^{10,14,15}$ In agreement with this, serum $\mathrm{C}_{26: 0} / \mathrm{C}_{22: 0}$ and $\mathrm{C}_{24: 0} / \mathrm{C}_{22: 0}$ ratios increase approximately threefold in $\mathrm{ACOX} 1^{-1-}$ mice compared with wild-type mice, whereas these $\mathrm{ACOX} 1^{-1-}$ humanized mice (discussed below) showed levels similar to those in wild-type mice (see Supplemental Figure S2 at http://ajp.amjpathol.org). 

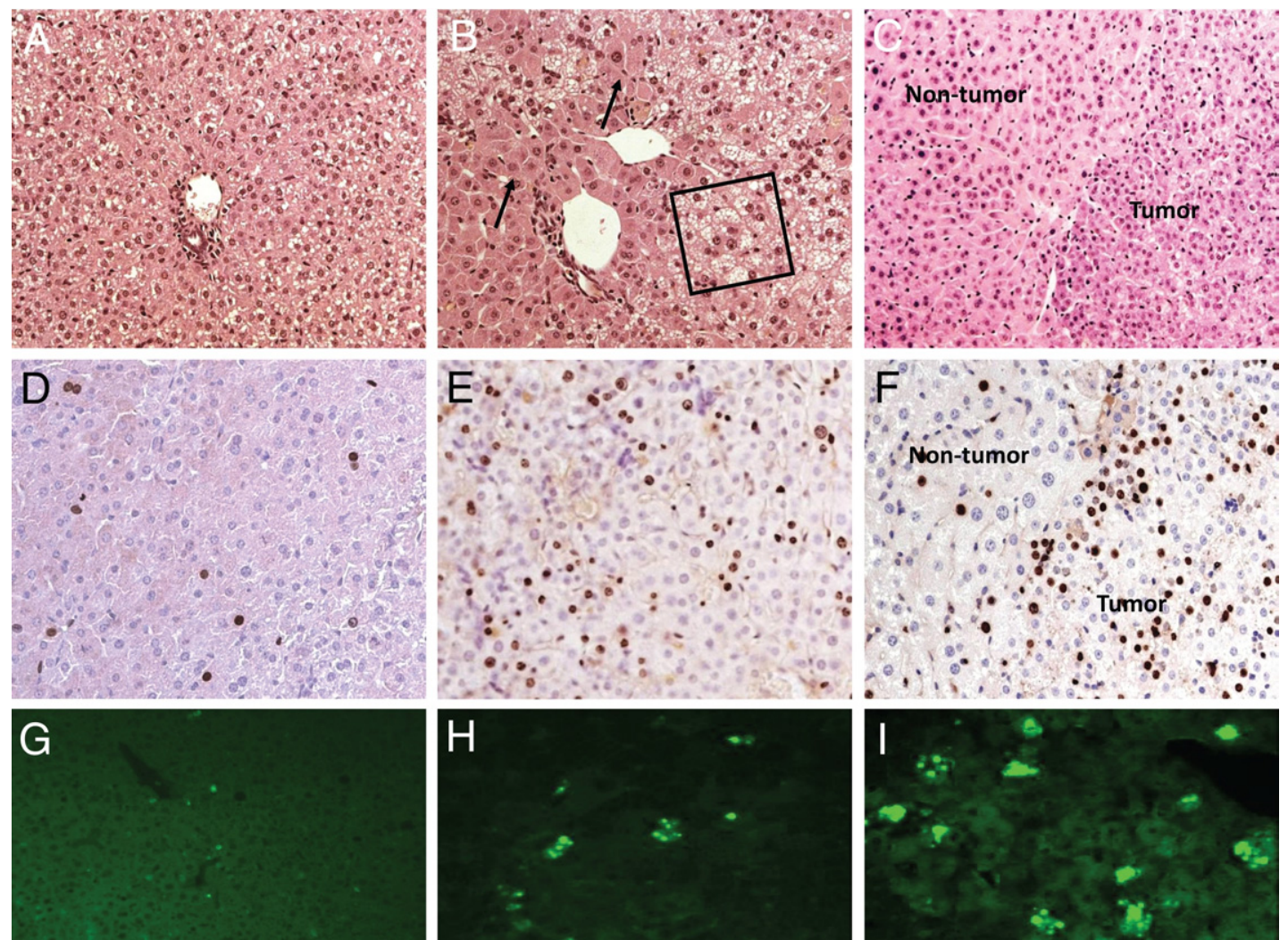

Figure 2. Age-related hepatocellular proliferation with abatement of hepatic steatosis in $\mathrm{ACOX} 1^{-1-}$ mice. $\operatorname{H\& E}(\mathbf{A}-\mathbf{C})$, BrdUrd (D-F), and terminal deoxynucleotidy transferase-mediated dUTP nick-end labeling $(\mathbf{G}-\mathbf{I})$ staining of liver from 2-week-old $(\mathbf{A}, \mathbf{D}$, and $\mathbf{G})$, 5-month-old $(\mathbf{B}, \mathbf{E}$, and $\mathbf{H})$, and 1-year-old $(\mathbf{C}, \mathbf{F}$, and $\mathbf{I})$ ACOX1 mice. Boxed area in $\mathbf{B}$ indicates microvesicular steatosis; arrows point to regenerated hepatocytes. In $\mathbf{C}$ and $\mathbf{F}$, tumor and nontumor areas are shown.

The expression levels of selected ER stress-related genes revealed increases in ATF4, CHOP, GADD45 $\alpha$, p53, and p8 in a time-dependent manner in $\mathrm{ACOX} 1^{-1-}$ mouse livers (Figure $3, A$ and $B$ ). QPCR results further confirmed that ER stress response genes $\mathrm{CHOP}$, TRB3, Bax, Bclll, and p8 are also increased in ACOX1 $1^{-1-}$ mouse liver (Figure $3 C$ ). Transcription factor p8 mRNA expression in the wild-type mouse liver was low, but in the

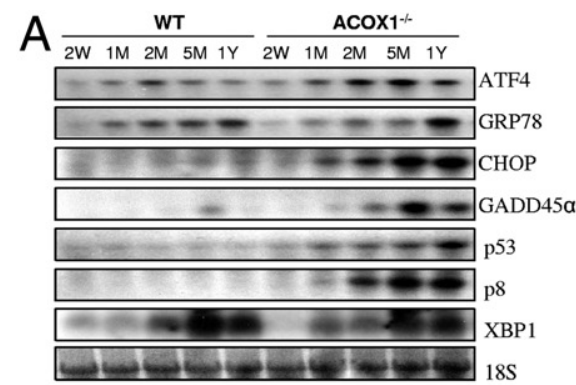

D

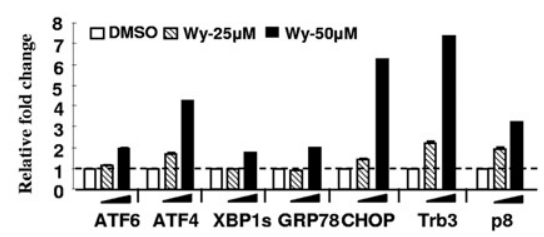

B

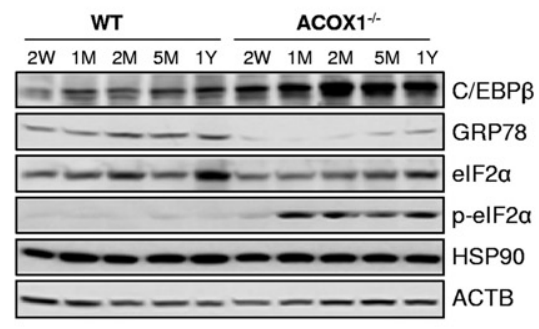

E

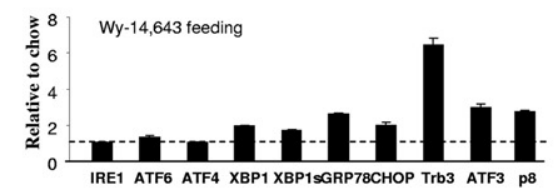

C

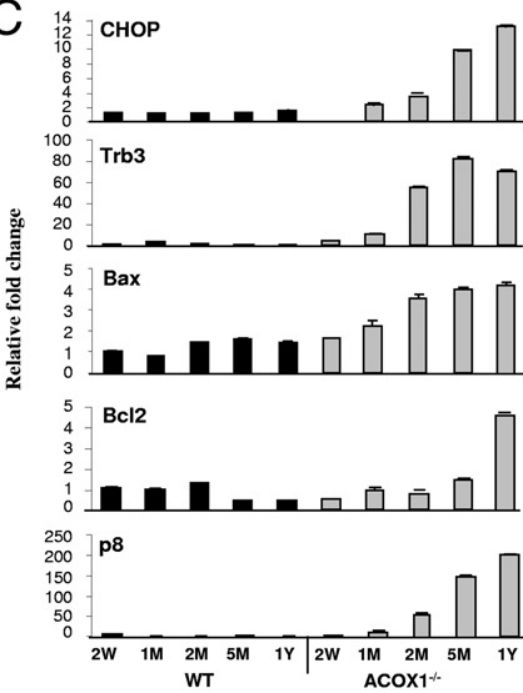

Figure 3. Spontaneous PPAR $\alpha$ activation in ACOX $1^{-/-}$mouse liver aggravates ER stress. A: Northern blot analysis of wild-type (WT) and ACOX1 ${ }^{-/-}$mouse liver RNA. Mice 2 weeks old (W), 1, 2, and 5 months old (M), and 1 year old (Y). B: Western blot analysis of liver protein (20 $\mu \mathrm{g}$ protein). ACTB served as loading control. C: qPCR analysis of liver RNA from wild-type (WT) and ACOX1 ${ }^{-1}$ mice. D: qPCR analysis of ER stress gene expression in primary hepatocytes treated with Wy-14,643. E: ER stress response gene expression in the liver of wild-type mice fed Wy-14,643 for 4 days was analyzed by qPCR. Fold change presented represents normalization of Wy-14,643 group against chow control. $18 \mathrm{~S}$ was used as internal control. 


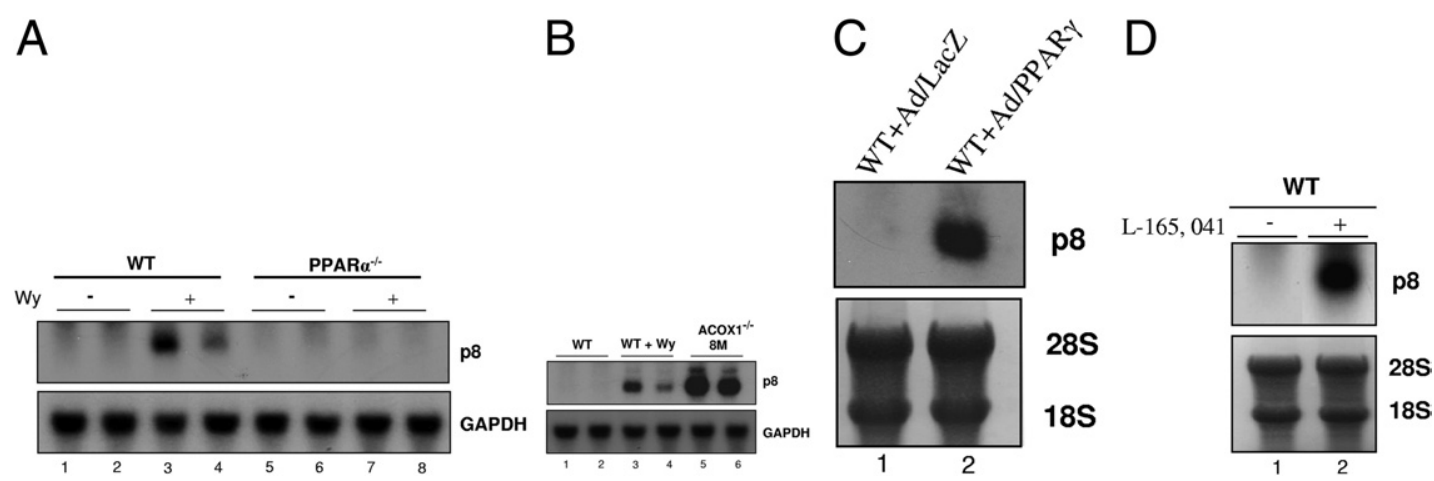

Figure 4. Induction of $\mathrm{p} 8$ mRNA in liver by PPAR isoforms. Northern blot analyses: (A) p 8 mRNA in wild-type (PPAR $\alpha^{+/+}$) (WT; lanes $\mathbf{3}$ and 4) and PPAR $\alpha^{-/-}$ (lanes 7 and 8) mouse livers treated for 4 days with PPAR $\alpha$ ligand Wy-14,643 (0.125\% w/w). Untreated controls (lanes $\mathbf{1}$ and $\mathbf{2}$; lanes $\mathbf{5}$ and 6). B: Endogenous ligand-mediated activation of PPAR $\alpha$ in ACOX1 $1^{-1-}$ mouse liver increases hepatic p 8 mRNA content. Wild-type mice without (lanes $\mathbf{1}$ and $\mathbf{2}$ ) or with Wy-14,643 treatment (lanes $\mathbf{3}$ and $\mathbf{4}$ ) and untreated 8-month-old ACOX1 $1^{-1-}$ mice (lanes $\mathbf{5}$ and $\mathbf{6}$ ). GAPDH is shown as loading control (A and $\left.\mathbf{B}\right)$. C: Expression of p8 in mouse liver in response to PPAR $\gamma$ overexpression using adenovirus PPAR $\gamma(\mathrm{Ad} / \mathrm{PPAR} \gamma$ ) (lane $\mathbf{2}$ ). Ad/LacZ (lane 1) served as control. D: PPAR $\beta / \delta$ activation increases p8 mRNA content in liver. WT mouse injected i.p with PPAR $\beta / \delta$ ligand, L-165,041 (1 mg/day for 5 days). $28 \mathrm{~S}$ and $18 \mathrm{~S}$ are shown as loading controls.

ACOX $1^{-1-}$ mouse, p8 mRNA expression increased with age (Figure 3, A and C). Reduction of GRP78 protein content in $\mathrm{ACOX} 1^{-1-}$ mouse livers was noted on Western blotting (Figure 3B). In $\mathrm{ACOX} 1^{-1-}$ mouse liver, the p-elF2 $\alpha$ protein level increased significantly beginning at 1 month of age, whereas the total amount of elF2 $\alpha$ protein did not change (Figure 3B). An increase in p-elF2 $\alpha$ was associated with upregulation of ATF4 expression and its target gene, transcription factor $\mathrm{CHOP}$, in $\mathrm{ACOX} 1^{-1-}$ mice (Figure 3A).

\section{Induction of ER Stress in Liver by Upregulation of Transcription Factor $p 8$ by PPAR Isoforms}

Fatty acids and their metabolic derivatives serve as potent endogenous ligands in ACOX $1^{-1-}$ mice to activate $\operatorname{PPAR} \alpha$, which may further induce ER stress in ACOX $1^{-1-}$ mice. ${ }^{8,10,14,15}$ Primary hepatocytes treated with synthetic PPAR $\alpha$ ligand Wy-14,643 (50 $\mu \mathrm{mol} / \mathrm{L})$ in the culture medium showed increases in the mRNA levels of ER stress response genes, in particular, ATF4, CHOP, TRB3, and p8 (Figure 3D). Wild-type mice fed Wy-14,643 (0.125\% $w / w)$ in powdered chow for 4 days revealed increases in mRNA expression for ER stress response genes in liver as assessed by qPCR. The relative mRNA expression of GRP78, Trb3, ATF3, and p8 were increased approximately threefold compared with the chow controls (Figure $3 \mathrm{E})$. These data indicate the development of significant ER stress in liver with activation of PPAR $\alpha$. Furthermore, p8 mRNA levels increased in livers of wild-type mice but not in PPAR $\alpha^{-1-}$ mice fed Wy-14,643 (Figure 4, A and B). Likewise, spontaneous activation of PPAR $\alpha$ by endogenous ligands in $\mathrm{ACOX} 1^{-1-}$ mouse liver caused a marked increase in hepatic p8 mRNA content (Figure 4B). Expression of GRP78 in untreated and Wy-14, 643-treated PPAR $\alpha^{-1-}$ mouse livers was reduced as compared with that in wild-type mice, suggesting PPAR $\alpha$-activated dependency of ER stress (see Supplemental Figure S3 at http://ajp.amjpathol.org). Overexpression of PPAR $\gamma$ in the liver by adenovirus transduction also resulted in an increase in p8 mRNA expression (Figure 4C). Levels of p8
mRNA also increased in the liver of a mouse treated with PPAR $\beta / \delta$ ligand L-165,041 (Figure 4D). Based on these observations, we consider p8 as a possible target gene for all three PPAR isoforms.

We found three putative peroxisome proliferator-response elements (PPREs) ${ }^{17}$ in the p8 promoter and designated these as P1, P2, and P3 (Figure 5A). These consist of an imperfect hexamer separated by 1 bp (DR1-like). The nucleotide sequences and positions of PPREs in p8 are as follows: p8-P1 (5'-AGGTCAGAGGTTG-3'; -2714/ -2702); p8-P2 (5'-TGACCCACAGCCT-3'; -1339/-1327), and p8-P3 (5'-AGACCTCAGGCCA-3'; -583/-571). Gel mobility shift assays revealed that all three in vitro translated PPAR isoforms $(-\alpha,-\beta / \delta$, and $-\gamma)$ and $\operatorname{RXR} \alpha$ bind variably as PPAR/RXR heterodimers to P1 and P3 sites. PPAR $\alpha$ and PPAR $\gamma$ bind more prominently to P1 and P3, respectively (Figure $5 \mathrm{~B}$ ). Of the three isoforms, only PPAR $\alpha$ showed a minimally detectable binding to P2 (Figure 5B). Competitive electrophoretic mobility shift assay (EMSA) confirmed binding specificity of $\mathrm{P} 1$ and $\mathrm{P} 3$ to PPAR $\alpha$ and PPAR $\gamma$, respectively (Figure $5 \mathrm{C}$ ). ChIP assays revealed that PPAR $\alpha$ binds all three PPREs on p8 promoter in Wy-14,643-fed wild-type mouse liver, but not in PPAR $\alpha^{-1-}$ mouse liver (Figure 5D). ChIP assay for PPAR $\gamma$ occupancy on p8 promoter showed that PPAR $\gamma$ bound to P1 and P3 PPRE in both wild-type and PPAR $\alpha^{-1-}$ mouse liver (Figure 5E).

Our data suggest that PPAR $\alpha$ exerts a direct action on the mouse p8 promoter to upregulate its expression resulting in progressively increased expression of $p 8$ in ACOX $1^{-1-}$ mice. When p8 was knocked down using siRNAs in PPAR $\alpha^{-1-}$ mouse embryonic fibroblasts, there was an alleviation of ER stress in response to reduced expression of $p 8$. The expression of ER stress response genes, such as ATF4, CHOP, XBP1s, GRP78, and Trb3 was inhibited (see Supplemental Figure S4 at http://ajp.amjpathol.org). These results are consistent with an earlier report that p8 may regulate ATF4, $\mathrm{CHOP}$, and TRB3. ${ }^{37}$ These results further extend our knowledge that p8, a novel PPAR $\alpha$ target gene, can induce ER stress. 
A
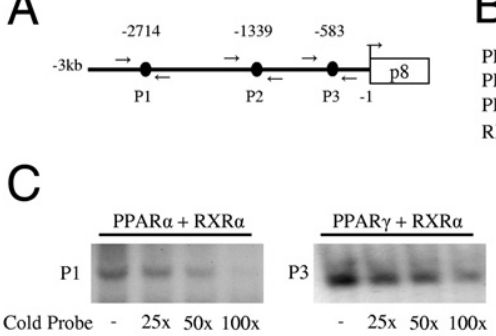

D

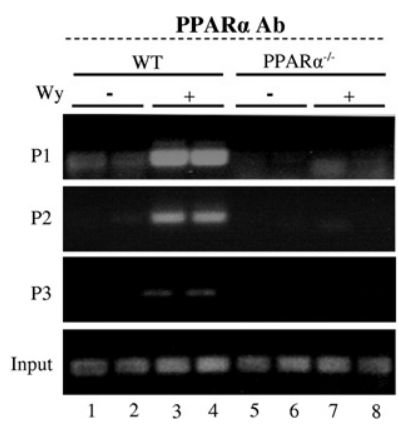

\section{B}
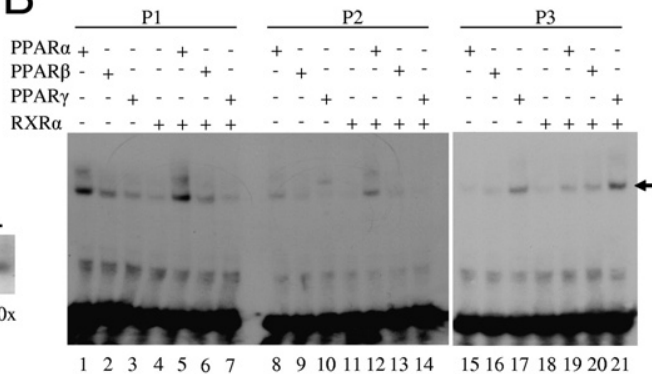

E

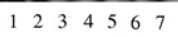

891011121314 15161718192021

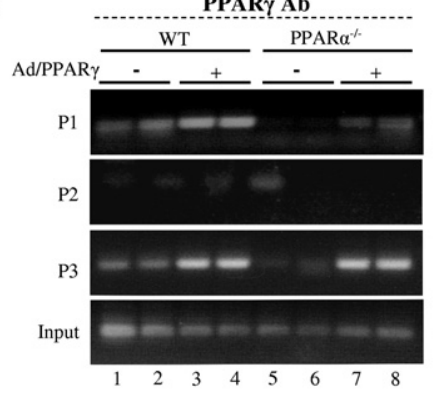

Figure 5. Regulation of $\mathrm{p} 8$ promoter by $\mathrm{PPAR}$ isoforms. A: Schematic representation of $\mathrm{p} 8$ promoter upstream of the first ATG with three potential PPREs (P1 at -2714, P2 at -1339 , and P3 at -583). Arrows represent primers used for ChIP analysis. B: Binding analyses of PPAR isoforms using EMSA. Arrow represents product in EMSA binding assay. C: Specific binding for P1 with $\operatorname{PPAR} \alpha / \operatorname{RXR} \alpha$ and $\mathrm{P} 3$ with $\operatorname{PPAR} \gamma / \mathrm{RXR} \alpha$ were confirmed by competitive EMSA using 25-, 50-, or 100 -fold molar excess of cold oligonucleotide. D and E: ChIP assays to examine recruitment of $\operatorname{PPAR} \alpha(\mathbf{D})$ and PPAR $\gamma(\mathbf{E})$ on $\mathrm{p} 8$ promoter. Chromatin extracts, prepared from liver of wild-type and PPAR $\alpha^{-1-}$ mice fed normal or Wy-14-643 $(0.125 \% \mathrm{w} / \mathrm{w})-$ containing chow for 4 days, were used for immuonoprecipitation with PPAR $\alpha$ antibody (PPAR $\alpha \mathrm{Ab})$. Promoter-occupancy was observed on all three PPREs (P1, P2, and P3) with differential affinity on treatment with PPAR $\alpha$ agonist (lanes $\mathbf{3}$ and $\mathbf{4}$ ), whereas no binding was observed in PPAR $\alpha^{-/-}$mice (lanes 5-8). For in vivo occupancy by PPAR $\gamma$, chromatin extracts prepared from wild-type and PPAR $\alpha^{-1-}$ mice injected with Ad/PPAR $\gamma$ were immmunoprecipitated using PPAR $\gamma$ antibody (PPAR $\gamma \mathrm{Ab})$. Input represents control in $\mathbf{D}$ and $\mathbf{E}$.

\section{Generation of $A C O X 1^{-/-}$Mice with Human ACOX1 Transgene}

We generated human ACOX1 transgenic mice using the BAC transgenic technique (Figure $6 \mathrm{~A}$ ) and crossed these with $\mathrm{ACOX} 1^{-1-}$ mice to generate $\mathrm{ACOX} 1^{-1-\mathrm{h}+}$ mice. We measured the expression levels of mouse ACOX1 (mACOX1) (see Supplemental Figure S5A at http://ajp. amjpathol.org) and human ACOX1 (hACOX1) (see Supplemental Figure S5B at $h$ ttp://ajp.amjpathol.org) mRNA in different tissues, and show that hACOX1 mRNA is present in many tissues in $\mathrm{ACOX} 1^{-1-\mathrm{h}+}$ mice. As anticipated, the age- and sex-matched $\mathrm{ACOX} 1^{-/-\mathrm{h}+}$ humanized mice appeared similar in body size to wildtype mice, suggesting that the human ACOX1 is functionally capable of preventing deficiency of mouse ACOX1. ACOX $1^{-l-h+}$ humanized mice did not develop fatty liver, and hepatic triglyceride content appeared similar to that of wild-type control mice (see Supplemental Figure S1 at http://ajp.amjpathol.org). The spontaneous and sustained activation of PPAR $\alpha$ target genes noted in $\mathrm{ACOX} 1^{-1-}$ mouse liver was not observed in $\mathrm{ACOX} 1^{-/-\mathrm{h}+}$ mouse liver (Figure 6, B and C). Serum $C_{26: 0} / C_{22: 0}$ and $\mathrm{C}_{24: 0} / \mathrm{C}_{22: 0}$ ratios in humanized mice were similar to that noted in wild-type mice (see Supplemental Figure S2 at http://ajp.amjpathol.org).

As expected, in both $\mathrm{ACOX} 1^{-1-}$ and $\mathrm{ACOX} 1^{-1-\mathrm{h}+}$ mouse livers, no mouse ACOX1 (mACOX1) mRNA was detected (Figure 6B). Human ACOX1 mRNA was detected in ACOX $1^{-l-h+}$ mouse liver (Figure 6B). ACOX1 protein was undetected in $\mathrm{ACOX} 1^{-1-}$ but was present in ACOX $1^{-1-\mathrm{h}+}$ mouse liver (Figure $6 \mathrm{C}$ ). As expected, the mRNA and protein concentrations of PPAR $\alpha$ target genes such as LCAD, L-PBE, and PTL ${ }^{14}$ increased in ACOX $1^{-1-}$ mouse livers because of activation of PPAR $\alpha$ by unmetabolized biological ligands (Figure 6B). Of interest is that a PPAR $\gamma$ target gene aP2 mRNA level is also increased in $\mathrm{ACOX} 1^{-1-}$ mouse liver, implying that other PPAR $\gamma$ target genes may also be upregulated in ACOX1 deficiency (Figure 6B). Expression of human ACOX1 transgene in $\mathrm{ACOX} 1^{-I-h+}$ mouse liver abrogated the spontaneous activation of $\operatorname{PPAR} \alpha$, resulting in the failure of induction of the target genes (Figure 6, B and C). Likewise, PPAR $\gamma$ target gene aP2 induction was also abrogated in $\mathrm{ACOX} 1^{-1-\mathrm{h}+}$ mouse liver (Figure 6B). Regenerated hepatocytes in $\mathrm{ACO} \times 1^{-1-}$ mouse liver showed profound increase in the number of peroxisomes, indicating endogenous activation of PPAR $\alpha$, whereas hepatocytes with microvesicular steatosis in these livers revealed no peroxisome proliferation (Figure $6 \mathrm{D})$. Livers of $\mathrm{ACOX} 1^{-I-\mathrm{h}+}$ mice showed no evidence of steatosis and steatohepatitis and no peroxisome proliferation (Figure 6D), indicating that the introduction of human ACOX1 gene prevents the development of ACOX1 null phenotypic characteristics.

\section{Prevention of Liver Carcinogenesis in ACOX $1^{-1-h+}$ Mice by ER Stress Relief}

ACOX1 null mice with introduced human ACOX1 gene $\left(\mathrm{ACOX} 1^{-1-\mathrm{h}+}\right)$ did not develop steatosis and steatohepatitis. There was no evidence of spontaneous PPAR $\alpha$ activation, as there was no increase in the mRNA levels of PPAR $\alpha$ target genes in these ACOX $1^{-1-\mathrm{h}+}$ mouse livers (Figure 6, B-D). ACOX1 $1^{-1-\mathrm{h}+}$ mice fed $\mathrm{Wy}-14,643$, a synthetic PPAR $\alpha$ ligand, showed induction of human ACOX1 mRNA in liver, and this up-regulation of human ACOX1 mRNA appeared essentially similar to the induction of mouse ACOX1 mRNA in wild-type mice fed Wy14643 (see Supplemental Figure S5, C and D at $h t t p: / /$ ajp.amjpathol.org). Human ACOX1 gene in these BAC transgenic mice contains a PPRE consisting of $5^{\prime}$-AGGTCA G CTGTCA-3', and this gene responds to the tran- 

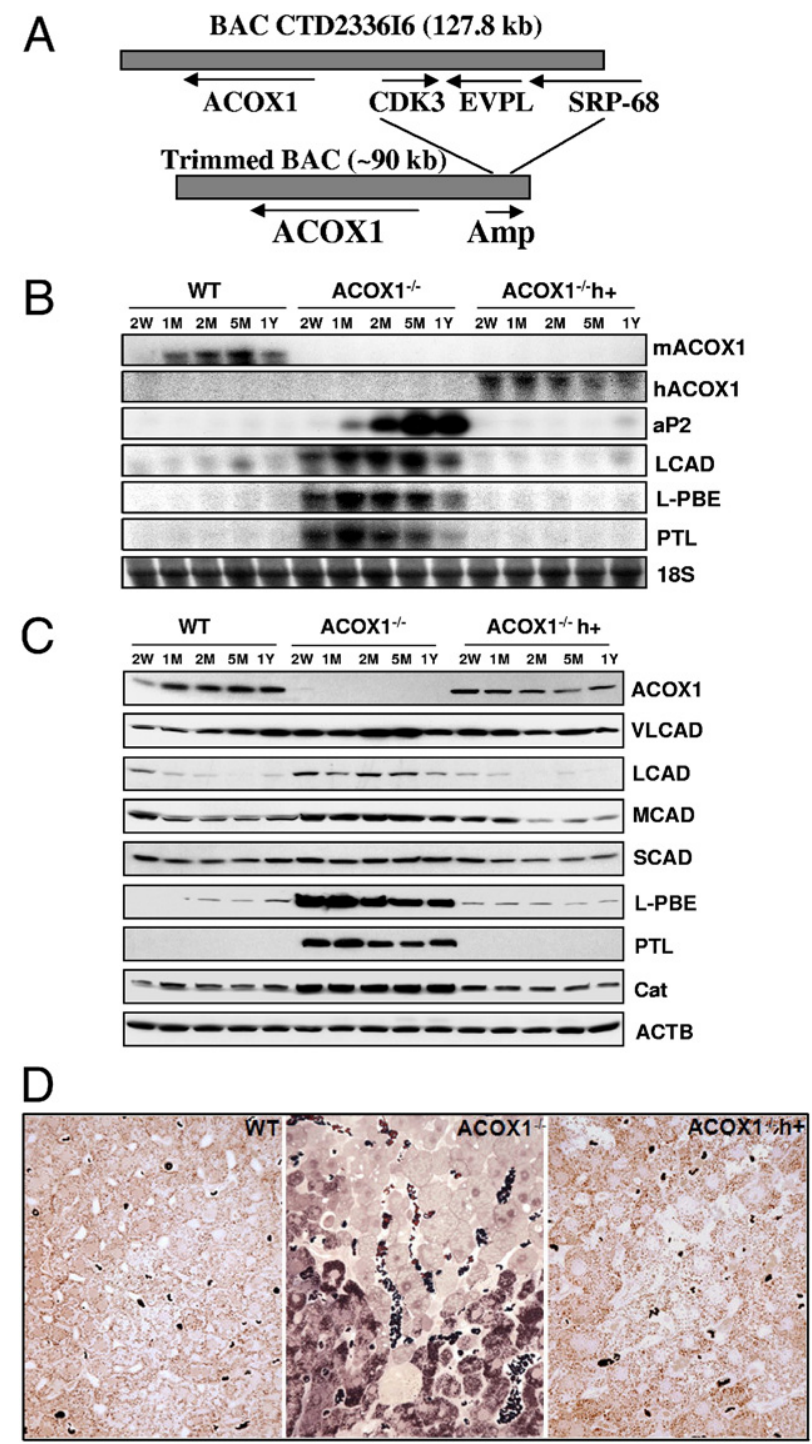

Figure 6. Generation of ACOX1 $1^{-/-\mathrm{h}+}$ mice. A: Human ACOX1 BAC clone CTD2336I6. AMP (ampicillin-resistant gene); CDK3 (cyclin-dependent kinase 3); EVPL (envoplakin); and SRP68 (signal recognition particle $68 \mathrm{kDa}$ ). B: Northern blot analysis of PPAR $\alpha$ target genes involved in fatty acid oxidation in liver. C: Western blot analysis. Protein levels of PPAR $\alpha$-regulated genes involved in fatty acid oxidation. D: Diaminobenzidine histochemical localization of peroxisomal catalase to assess peroxisome population in liver. Dark brown dots in the cytoplasm represent peroxisomes in these semithin sections $(0.5 \mu \mathrm{mol} / \mathrm{L})$. In ACOX $1^{-/-}$livers regenerated hepatocytes show peroxisome proliferation (intense brown dots) which differ from hepatocytes with microvesicular steatosis (foamy cytoplasm).

scriptional activation by PPAR $\alpha$ ligand Wy-14,643. ${ }^{38-40}$ These findings negate the mistaken notion that human ACOX1 promoter is nonfunctional or noninducible and minimizes the potential risk to human beings of chronic exposure to PPAR $\alpha$ ligands. ${ }^{41}$ If human ACOX1 gene is uninducible as proposed, ${ }^{41}$ one would expect severe metabolic problems and hepatic dysfunction in human beings, since these individuals would not be able to properly metabolize endogenous PPAR $\alpha$ ligands. ${ }^{10,17,40}$ Furthermore, none of the ACOX $1^{-l-\mathrm{h}+}$ mice developed hepatocellular carcinomas, whereas, as expected, all ACOX $1^{-1-}$ mice developed liver tumors by 8 to 14 months of age. To ascertain whether the ER stress noted in $\mathrm{ACOX} 1^{-1-}$ mouse liver (Figure $3, \mathrm{~A}-\mathrm{C}$ ) is relieved in $\mathrm{ACOX} 1^{-1-\mathrm{h}+}$ mouse liver, we studied the expression of these ER stress response genes CHOP, TRB3, Bax, Bclll, and p8 by qPCR in mice 2 weeks to 1 year old (data not shown). The ER stress response increased progressively with age in $\mathrm{ACOX} 1^{-1-}$ mouse liver, whereas the expression of these genes in $\mathrm{ACOX} 1^{-1-\mathrm{h}+}$ mouse liver appeared similar to that seen in wild-type controls, implying prevention of ER stress by human ACOX1 transgene expression. Furthermore, in ACOX $1^{-1-h+}$ mouse liver, increases in other ER stressrelated genes such as GRP78, p-elF2a, C/EBP were not noted (data not shown), indicating the prevention of ER stress in $\mathrm{ACOX} 1^{-1-}$ mice with the expression of human ACOX1 gene.

\section{Discussion}

ACOX1 deficiency, which affects the metabolism of very long chain fatty acyl-CoAs and certain other fatty acid derivatives, presents an ideal murine model system for studying the role of steatohepatitis as well as sustained hyperactivation of PPAR $\alpha$ in the development of liver tumors. ${ }^{8,10}$ Furthermore, because disturbances of fatty acid metabolism in liver constitute a common thread linking steatosis and steatohepatitis caused by alcoholic and nonalcoholic conditions, as well as by consumption of high-fat or high-carbohydrate diets, the insights gained from the current work might be applicable for further understanding of the pathogenesis of fatty liver diseases. ${ }^{5,18-22,37,42-44}$ In the present study, we show that ACOX1 deletion is associated with augmented levels of ER stress in the liver, most likely caused by a cascade of events initiated by fatty acid intermediates that remain as unmetabolized, putatively toxic substrates of this key lipid-metabolizing enzyme. ${ }^{10,17,44}$ Sustained enhancement of ER stress in mice nullizygous for ACOX1 gene is likely to initiate fatty change in liver and contribute to a plethora of events leading to liver cancer. ${ }^{10}$ Our experimental results are consistent with the following scenario. Initially, the disruption of ACOX1 gene in the mouse leads to disturbances in the peroxisomal fatty acid $\beta$-oxidation pathway, resulting in increased intracellular levels of unmetabolized very long chain saturated fatty acids and their fatty acyl-CoAs. ${ }^{10,44}$ These unoxidized toxic substrates of ACOX1, as well as lipid derivatives such as triglycerides, compromise liver function, contributing to the development of fat-laden liver cells and promoting their apoptosis by inducing ER stress. Death of hepatocytes overloaded with fat results in the release of toxic fatty acids/derivatives that incite the onset of steatohepatitis and exaggerated ER stress. ${ }^{5,18}$ Apoptotic cell death of some steatotic hepatocytes in $\mathrm{ACOX} 1^{-1-}$ liver then imparts a signal for neighboring hepatocytes to proliferate. These newly formed hepatocytes become resistant to steatosis, but manifest pleiotropic changes consistent with sustained PPAR $\alpha$ activation by endogenous ligands of this receptor that remain unmetabolized in the absence of ACOX 1. ${ }^{10,17}$ PPAR $\alpha$ activation increases fatty acid oxidation systems that increased activity of mitochondrial 
$\beta$-oxidation system can metabolize a bulk of short- and medium-chain fatty acid to prevent steatotic alteration in hepatocytes that exhibit enormous increases in peroxisome populations. ${ }^{10}$ Accordingly, a functional ACOX1 under normal physiological conditions plays a pivotal role in minimizing ER stress in liver by degrading endogenous PPAR $\alpha$ ligands.

In accordance with the foregoing, we show evidence for a defective unfolded protein response signaling in the ACOX $1^{-1-}$ mouse liver, as exemplified by increases in ER stress effectors such as phosphorylated elF-2 $\alpha$ (pelF2 $\alpha$ ), ATF4, CHOP (CHOP10), GADD45 $\alpha$, TRB3, and the transcriptional regulator p8 (Figures 3 and 4). These age-progressive alterations are indicative of unresolved, ER stress in the ACOX1 $1^{-1-}$ mouse liver. TRB3, a novel target for ATF4/CHOP pathway, is known to participate in CHOP-dependent cell death. ${ }^{45,46} \mathrm{CHOP}$ is known to interfere with $\mathrm{C} / \mathrm{EBP} \alpha$, a transcription factor involved in hepatic gluconeogenesis and lipid homeostasis. ${ }^{19,42,43}$ Increased levels of $\mathrm{CHOP}$ expression with antecedent decrease in $\mathrm{C} / \mathrm{EBP} \alpha$ and increased phosphorylation of elF2 $\alpha$ (together with decreased fatty acid oxidation) result in disturbances in hepatic lipid metabolism, contributing to the development of fatty liver in $\mathrm{ACOX}^{-1-}$ mice. Increased phosphorylation of elF2 $\alpha$ leads to upregulation of transcription factor ATF4, which further activates CHOP and GADD34. ${ }^{20-22,24}$ Induction of proapoptotic transcription factor $\mathrm{CHOP}$ expression in $\mathrm{ACOX}_{1}{ }^{-1-}$ mouse liver indicates prolonged ER stress, which is closely associated with the progression of apoptosis (Figures 2 and 3). In $\mathrm{ACOX} 1^{-1-}$ mouse liver, GRP78 is generally decreased at both mRNA and protein levels. Several studies have shown that GRP78 expression is either increased or decreased under ER stress. ${ }^{22} \mathrm{~A}$ decrease in GRP78 expression has been shown to enhance mitochondrial permeability and augmented apoptosis in H460 cells during ER stress. ${ }^{47}$ Knockdown of GRP78 by siRNA increased $\mathrm{CHOP}$ expression. ${ }^{48}$ Reduction in GRP78 signaling in ACOX1 $1^{-1-}$ mouse liver, beginning at a very early age (ie, 2 weeks of age) further confirms that ER stress begins early in ACOX1 null livers and is possibly linked to the steatohepatitis phase. It is worth noting that GRP78 protein increased in older $\mathrm{ACOX} 1^{-1-}$ mouse livers (Figure $3 \mathrm{~B}$ ). Furthermore, in the $\mathrm{ACOX} 1^{-1-}$ mouse liver, age-related increases in proapoptotic Bax expression were noted when compared with the expression of the antiapoptotic factor Bcl-2 (Figure 3C). The intracellular ratio of $\mathrm{Bax} / \mathrm{Bcl}-2$ proteins can influence the ability of a cell to respond to an apoptotic signal, ${ }^{49}$ and, in large part, we show that this ratio is higher in $\mathrm{ACOX} 1^{-1-}$ mouse liver than in wild-type mice. It is also important to note that TRB3, a novel target for ATF4/CHOP pathway, is also known to participate in $\mathrm{CHOP}$-dependent cell death. ${ }^{49}$ TRB3 has been shown to be regulated by PPAR $\alpha,{ }^{50}$ and because PPAR $\alpha$ is activated in a sustained manner in ACOX $1^{-1-}$ mouse liver, the high levels of TRB3 expression appear to be consistent with the proposed regulatory pathway (Figure 7). TRB3 is also upregulated by reactive oxygen species as well as free fatty acids. ${ }^{51,52}$ These factors also appear to be operative in $\mathrm{ACOX} 1^{-1-}$

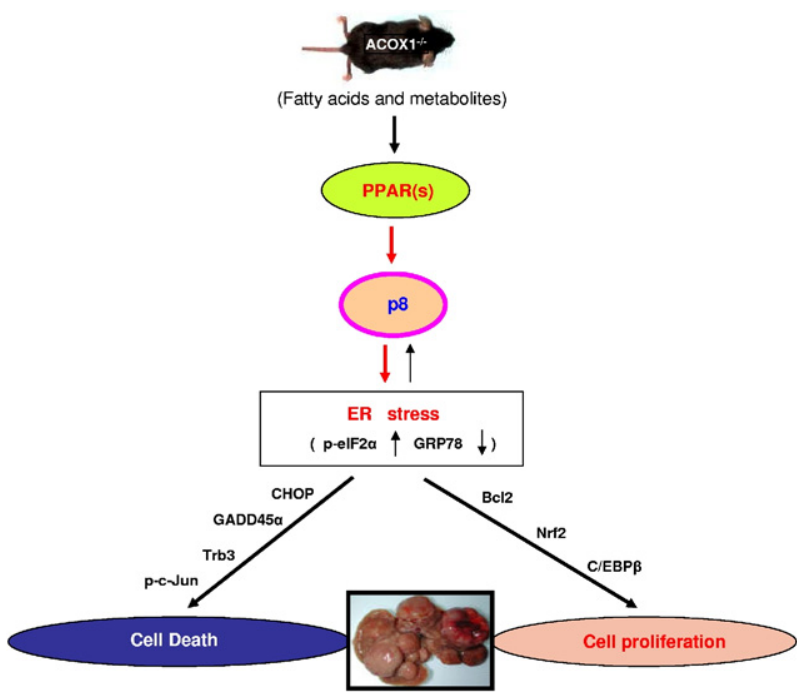

Figure 7. Model to illustrate the role of PPARs and p8 in inducing ER stress in ACOX1-deficient mouse liver phenotype. In $\mathrm{ACOX}^{-1-}$ mouse liver, there is evidence for the activation of both PPAR $\alpha$ and PPAR $\gamma$ (target gene induction described in Figure $6 \mathrm{~B}$ ) and thus contribute to p8 induction and p8regulated ER stress genes. In addition, $\mathrm{p} 8$ is induced by PPAR $\beta / \delta$ synthetic ligand, but whether $\mathrm{p} 8$ is activated spontaneously in $\mathrm{ACOX} 1^{-/-}$liver is unclear.

mouse liver, in addition to $\mathrm{CHOP}$ and $\operatorname{PPAR} \alpha$, in inducing TRB3.

Of interest is that this study presents evidence for the regulatory role of PPAR $\alpha$ in the upregulation of transcription regulator $\mathrm{p} 8$ in $\mathrm{ACOX}^{-1-}$ mouse liver (Figures 4 and 5). Generally, p8 is considered a survival and cell proliferation signal with an impact on tumor progression and metastasis. $^{37,42}$ It also mediates apoptosis by upregulating the ER stress response genes ATF4, CHOP, and TRB3. ${ }^{37}$ In ACOX $1^{-1-}$ mouse liver, p8, ATF4, CHOP, GADD $45 \alpha$, and TRB3 show a similar pattern of increased expression. It should be noted that $\mathrm{p} 8$ is induced by ATF4, and evidence suggests that $\mathrm{p} 8$ also acts as a positive regulator of the transcriptional activator ATF4. ${ }^{29,53}$ The data presented here demonstrate that spontaneous induction of p8 in $\mathrm{ACOX} 1^{-1-}$ mouse liver is due to, at least in part, to sustained activation of PPAR $\alpha$ and also to PPAR $\gamma$, in view of the increase in the mRNA content of its target gene aP2 (Figure $6 \mathrm{~B}$ ). The induction of $\mathrm{p} 8 \mathrm{mRNA}$ by the synthetic ligands of PPAR $\alpha$ and PPAR $\beta / \delta$ in wild-type mice (Figure 4) further supports the proposed regulatory function of PPARs. We show here that the p8 gene promoter contains functional PPRE that appear to respond to all three PPAR isoforms (Figure 5). Thus, it appears that p8 is regulated by ATF4 and PPARs and possibly by other factors. Further studies are required to assess the role of transcription coactivators such as mediator subunit Med1 in p8-mediated ER stress. ${ }^{54}$

In conclusion, these studies present evidence for the role of ER stress in ACOX $1^{-1-}$ mouse liver in the ageprogressive phenomenon of steatosis, steatohepatitis, fibrosis, and the development of hepatocelular carcinoma. The progressive ER stress, which may be initiated by the fatty acid derivatives that remain unmetabolized and serve to activate $\operatorname{PPAR} \alpha$, may be critical for the development of hepatocellular carcinoma in $\mathrm{ACOX} 1^{-/-}$mice. 
Furthermore, all three PPAR isoforms appear to regulate the transcription of nuclear protein $\mathrm{p} 8$, which is a key player in ER stress. Finally, our data with $\mathrm{ACOX} 1^{-1-}$ mice expressing human ACOX1 transgene (ACOX $1^{-1-h+}$ humanized mice) clearly establish that functional expression of the human ACOX1 gene prevents the development of phenotypic features of ACOX1 deficiency and abrogates ER stress in liver.

\section{References}

1. Grundy SM: Obesity, metabolic syndrome, and cardiovascular disease. J Clin Endocrinol Metab 2004, 89:2595-2600

2. Angulo P, Lindor KD: Non-alcoholic fatty liver disease. J Gastroenterol Hepatol 2002, 17:S186-S190

3. Reddy JK, Rao MS: Lipid metabolism and liver inflammation. II. Fatty liver disease and fatty acid oxidation. Am J Physiol Gastrointest Liver Physiol 2006, 290:G852-G858

4. Anderson N, Borlak J: Molecular mechanisms and therapeutic targets in steatosis and steatohepatitis. Pharmacol Rev 2008, 60:311-357

5. Malhi H, Gores GJ: Molecular mechanisms of lipotoxicity in nonalcoholic fatty liver disease. Semin Liver Dis 2008, 28:360-369

6. Bugianesi E, Leone N, Vanni E, Marchesini G, Brunello F, Carucci P, Musso A, De Paolis P, Capussotti L, Salizzoni M, Rizzetto M: Expanding the natural history of nonalcoholic steatohepatitis: from cryptogenic cirrhosis to hepatocellular carcinoma. Gastroenterology 2002, 123: $134-140$

7. Anstee QM, Goldin RD: Mouse models in non-alcoholic fatty liver disease and steatohepatitis research. Int J Exp Pathol 2006, 87:1-16

8. Fan CY, Pan J, Chu R, Lee D, Kluckman KD, Usuda N, Singh I, Yeldandi AV, Rao MS, Maeda N, Reddy JK: Hepatocellular and hepatic peroxisomal alterations in mice with a disrupted peroxisomal fatty acyl-coenzyme A oxidase gene. J Biol Chem 1996, 271:2469824710

9. Purushotham A, Schug TT, Xu Q, Surapureddi S, Guo X, Li X: Hepatocyte-specific deletion of SIRT1 alters fatty acid metabolism and results in hepatic steatosis and inflammation. Cell Metab 2009, 9:327-338

10. Fan CY, Pan J, Usuda N, Yeldandi AV, Rao MS, Reddy JK: Steatohepatitis, spontaneous peroxisome proliferation and liver tumors in mice lacking peroxisomal fatty acyl-CoA oxidase. Implications for peroxisome proliferator-activated receptor alpha natural ligand metabolism. J Biol Chem 1998, 273:15639-15645

11. Reddy JK: Nonalcoholic steatosis and steatohepatitis. III. Peroxisomal $\beta$-oxdiation, PPAR $\alpha$ and steatohepatitis. Am J Physiol Gastrointest Liver Physiol 2001, 281:G1333-G1339

12. Horie Y, Suzuki A, Kataoka E, Sasaki T, Hamada K, Sasaki J, Mizuno K, Hasegawa G, Kishimoto H, lizuka M, Naito M, Enomoto K, Watanabe S, Mak TW, Nakano T: Hepatocyter-specific Pten deficiency results in steatohepatitis and hepatocellular carcinomas. J Clin Invest 2004, 113:1774-1783

13. Lee SS, Pineau T, Drago J, Lee EJ, Owens JW, Kroetz DL, FernandezSalguero PM, Westphal H, Gonzalez FJ: Targeted disruption of the alpha isoform of the peroxisome proliferator-activated receptor gene in mice results in abolishment of the pleiotropic effects of peroxisome proliferators. Mol Cell Biol 1995, 15:3012-3022

14. Reddy JK, Hashimoto T: Peroxisomal beta-oxidation and peroxisome proliferator-activated receptor alpha: an adaptive metabolic system. Annu Rev Nutr 2001, 21:193-230

15. Yeldandi AV, Rao MS, Reddy JK: Hydrogen peroxide generation in peroxisome proliferator-induced oncogenesis. Mutat Res 2000, 448: $159-177$

16. Rusyn I, Asakura S, Pachkowski B, Bradford BU, Denissenko MF, Peters JM, Holland SM, Reddy JK, Cunningham ML, Swenberg JA: Expression of base excision DNA repair genes is a sensitive biomarker for in vivo detection of chemical-induced chronic oxidative stress: identification of the molecular source of radicals responsible for DNA damage by peroxisome proliferators. Cancer Res 2004, 64:1050-1057
17. Pyper SR, Viswakarma N, Yu S, Reddy JK: PPARalpha: energy combustion, hypolipidemia, inflammation and cancer. Nucl Recept Signal 2010, 8:e002

18. Kaplowitz N, Than TA, Shinohara M, Ji C: Endoplasmic reticulum stress and liver injury. Semin Liver Dis 2007, 27:367-377

19. Basseri S, Austin RC: ER stress and lipogenesis: a slippery slope toward hepatic steatosis. Dev Cell 2008, 15:795-796

20. Rutkowski DT, Wu J, Back SH, Callaghan MU, Ferris SP, Iqbal J, Clark R, Miao H, Hassler JR, Fornek J, Katze MG, Hussain MM, Song B, Swathirajan J, Wang J, Yau GD, Kaufman RJ: UPR pathways combine to prevent hepatic steatosis caused by ER stress-mediated suppression of transcriptional master regulators. Dev Cell 2008, 15:829-840

21. Flamment M, Kammoun HL, Hainault I, Ferre P, Foufelle F: Endoplasmic reticulum stress: a new actor in the development of hepatic steatosis. Curr Opin Lipidol 2010, 21:239-246

22. Kammoun $\mathrm{HL}$, Chabanon $\mathrm{H}$, Hainault I, Luquet S, Magnan C, Koike T, Ferré P, Foufelle F: GRP78 expression inhibits insulin and ER stressinduced SREBP-1C activation and reduces hepatic steatosis in mice. J Clin Invest 2009, 119:1201-1215

23. Armstrong JL, Flockhart R, Veal GJ, Lovat PE, Redfern CP: Regulation of endoplasmic reticulum stress-induced cell death by ATF4 in neuroectodermal tumor cells. J Biol Chem 2010, 285:6091-6100

24. Oyadomari S, Harding HP, Zhang Y, Oyadomari M, Ron D: Dephosphorylation of translation initiation factor 2alpha enhances glucose tolerance and attenuates hepatosteatosis in mice. Cell Metab 2008, 7:520-532

25. Naidoo N: The endoplasmic reticulum stress response and aging Rev Neurosci 2009, 20:23-37

26. Lin JH, Walter $\mathrm{P}$, Benedict Yen TS: Endoplasmic reticulum stress in disease pathogenesis. Annu Rev Pathol Mech Dis 2008, 3:399-425

27. Tabas I: The role of endoplasmic reticulum stress in the progression of atherosclerosis. Circ Res 2010, 107:839-850

28. Chowdhury UR, Samant RS, Fodstad O, Shevde LA: Emerging role of nuclear protein 1 (NUPR1) in cancer biology. Cancer Metastasis Rev 2009, 28:225-232

29. Goruppi S, Iovanna JL: Stress-inducible protein p8 is involved in several physiological and pathological processes. J Biol Chem 2010, 285:1577-1581

30. Reddy JK, Rao MS, Azarnoff DL, Sell S: Mitogenic and carcinogenic effects of a hypolipidemic peroxsiome proliferator, [4-chloro-6-(2,3xylidino)-2-pyrimidinylthio]acetic acid] (Wy-14,643), in rat and mouse liver. Cancer Res 1979, 39:152-161

31. Jia Y, Qi C, Kashireddi P, Surapureddi S, Zhu YJ, Rao MS, Le Roith D, Chambon P, Gonzalez FJ, Reddy JK: Transcription coactivator PBP, the peroxisome proliferator-activated receptor (PPAR)-binding protein, is required for PPARalpha-regulated gene expression in liver. $\mathrm{J}$ Biol Chem 2004, 279:24427-24434

32. Qi C, Zhu Y, Pan J, Yeldandi AV, Rao MS, Maeda N, Subbarao V, Pulikuri S, Hashimoto T, Reddy JK: Mouse steroid receptor coactivator-1 is not essential for peroxisome proliferator-activated receptor alpha-regulated gene expression. Proc Natl Acad Sci USA 1999, 96:1585-1590

33. Vluggens A, Androletti P, Viswakarma N, Jia Y, Matsumoto K, Kulik W, Khan M, Huang J, Guo D, Yu S, Sarkar J, Singh I, Rao MS, Wanders RJ, Reddy JK, Cherkaoui-Malki M: Functional significance of the two ACOX1 isoforms and their crosstalks with PPAR $\alpha$ and RXR $\alpha$. Lab Invest 2010, 90:696-708

34. Huang J, Iqbal J, Saha PK, Liu J, Chan L, Hussain MM, Hussain MM, Moore DD, Wang L: Molecular characterization of the role of orphan receptor small heterodimer partner in development of fatty liver. Hepatology 2007, 46:147-157

35. Qi C, Surapureddi S, Zhu YJ, Yu S, Kashireddy P, Rao MS, Reddy JK: Transcriptional coactivator PRIP, the peroxisome proliferator-activated receptor gamma (PPARgamma)-interacting protein, is required for PPARgamma-mediated adipogenesis. J Biol Chem 2003, 278:2528125284

36. Viswakarma N, Yu S, Naik S, Kashireddy P, Matsumoto K, Sarkar J, Sarkar J, Surapureddi S, Jia Y, Rao MS, Reddy JK: Transcriptional regulation of Cidea, mitochondrial cell death-inducing DNA fragmentation factor alpha-like effector $\mathrm{A}$, in mouse liver by peroxisome proliferator-activated receptor alpha and gamma. J Biol Chem 2007, 282:18613-18624

37. Carracedo A, Lorente M, Egia A, Blázquez C, García S, Giroux V, Malicet C, Villuendas R, Gironella M, González-Feria L, Piris MA, 
Iovanna JL, Guzmán M, Velasco G: The stress-regulated protein p8 mediates cannabinoid-induced apoptosis of tumor cells. Cancer Cell 2006, 9:301-312

38. Reddy JK, Goel SK, Nemali MR, Carrino JJ, Laffler TG, Reddy MK, Sperbeck SJ, Osumi T, Hashimoto T, ND Lalwani ND, Rao MS: Transcription regulation of peroxisomal fatty acyl-CoA oxidase and enoylCoA hydratase/3-hydroxyacyl-CoA dehydrogenase in rat liver by peroxisome proliferators. Proc Natl Acad Sci USA 1996, 83:1747-1751

39. Varanasi U, Chu R, Huang Q, Castellon R, Yeldandi AV, Reddy JK: Identification of a peroxisome proliferator-responsive element upstream of the human peroxisomal fatty acyl coenzyme A oxidase gene. J Biol Chem 1996, 271:2147-2155

40. Reddy JK: Peroxisome proliferators and peroxisome proliferator-activated receptor alpha: biotic and xenobiotic sensing. Am J Pathol 2004, 164:2305-2321

41. Woodyatt NJ, Lambe KG, Myers KA, Tugwood JD, Roberts RA: The peroxisome proliferator (PP) response element upstream of the human acyl-CoA oxidase gene is inactive among a sample human population: significance for species differences in response to PPs. Carcinogenesis 1999, 20:369-372

42. Salazar M, Carracedo A, Salanueva IJ, Hernández-Tiedra S, Lorente M, Egia A, Vázquez P, Blázquez C, Torres S, García S, Nowak J, Fimia GM, Piacentini M, Cecconi F, Pandolfi PP, González-Feria L, Iovanna JL, Guzmán M, Boya P, Velasco G: Cannabinoid action induces autophagy-mediated cell death through stimulation of ER stress in human glioma cells. J Clin Invest 2009, 118:1359-1372

43. Jaeschke H, Gores GJ, Cederbaum Al, Hinson JA, Pessayre D, Lemasters JJ: Mechanisms of hepatotoxicity. Toxicol Sci 2002, 65:166-176

44. Hashimoto T, Fujita T, Usuda N, Cook W, Qi C, Peters JM, Gonzalez FJ, Yeldandi AV, Rao MS, Reddy JK: Peroxisomal and mitochondrial fatty acid beta-oxidation in mice nullizygous for both peroxisome proliferator-activated receptor alpha and peroxisomal fatty acyl-CoA oxidase. Genotype correlation with fatty liver phenotype. J Biol Chem 1999, 274:19228-19236
45. Ohoka N, Yoshi S, Hattori T, Onozaki K, Hayashi H: TRB3, a novel ER stresss-inducible gene, is induced via ATF4-CHOP pathway and is involved in cell death. EMBO J 2005, 24:1243-1255

46. Kim I, Xu W, Reed JC: Cell death an dendoplasmic reticulum stress: disease relevance and therapeutic opportunities. Nat Rev Drug Discov 2008, 7:1013-1030

47. Shu CW, Sun FC, Cho JH, Lin CC, Liu PF, Chen PY, Chang MD, Fu HW, Lai YK: GRP78 and Raf-1 cooperatively confer resistance to endoplasmic reticulum-induced apoptosis. J Cell Physiol 2008, 215: 627-635

48. Zu K, Bihani T Lin A, Park YM, Mori K, Ip C: Enhanced selenium effect on growth arrest by BiP/GRP78 knockdown in p53-null human prostate cancer cells. Oncogene 2006, 25:546-554

49. Perlman H, Zhang X, 1, Chen MW, Walsh K, Buttyan R: An elevated bax/bcl-2 ratio corresponds with the onset of prostate epithelial cell apoptosis. Cell Death Differentiation 1999, 6:48-54

50. Koo SH, Satoh H, Herzig S, Lee CH, Hedrick S, Kulkarni R, Evans RM, Olefsky J, Montminy M: PGC-1 promotes insulin resistance in liver through PPAR- $\alpha$-dependent induction of TRB-3. Nat Med 2004, 10 530-534

51. Morse E, Schroth J, You YH, Pizzo DP, Okada S, Ramachandrarao S, Vallon V, Sharma K, Cunard R: TRB3 is stimulated in diabetic kidneys, regulated by the ER stress marker $\mathrm{CHOP}$ and is a suppressor of podocyte MCP-1. Am J Physiol Renal Physiol 2010, 299:F965-F972

52. Morgan NG: Fatty acids and $\beta$-cell toxicity. Curr Opin Clin Nutr Metab Care 2009, 12:117-122

53. Million Passe CM, Cooper G, Quirk CC: The murine p8 gene promoter is activated by activating factor 4 (ATF4) in the gonadotrope-derived $\mathrm{L} \beta \mathrm{T} 2$ cell line. Endocrine 2006, 30:81-91

54. Bai L, Jia Y, Viswakarma N, Huang J, Vluggens A, Wolins N, Jafari N, Rao MS, Borensztajn J, Yang G, Reddy JK: Transcription coactivator Mediator subunit Med1 is required for the development of fatty liver in the mouse. Hepatology 2011, 53:1164-1174 